\title{
Te Utu
}

Whangape, 1528, ko Korekore te whiwhia te maramataka.

Taiao and his army went hunting for birds and set snares. While they were there, Taiao saw the gutless pig, who killed his father twelve years ago. After Taiao saw Te Pō in the distance, he instructed his troops with his taiaha to stop and be stealthy. Taiao crouched under the cover of the bushes and watched, stalking Te Pō and his small ope.

While watching Te Pō, Taiao had intermittent, yet vivid flashbacks of the night his papa kāinga was attacked by Te Pō and his troops, 12 years ago.

"Iahaha!" screamed an intruder. "Dohhaaa!" barked others. The children were screaming, crying, and hiding in fear they would be killed. "Who are you? Why are you here, what do you want?" demanded Tūkaha-nui, Taiao's father.

"We are the warriors of Ngāti Tāngonge, of the tribe Ngāti Te Aewa, and we want your land and food. If you submit and leave without a fuss, we will leave you be," said Te Pō calmly.

"No. This is our land, our home. If you want it, you will have to kill us for it," declared Tūkaha.

"If you insist," said Te Pō, smugly.

Te Pō, adorned in his black korowai, black feathers in his black hair, stood in front of Tūkaha wielding 
his black taiaha. He taunted Tūkaha by performing various mocking ahai (taiaha formation poses). The warriors slowly circled each other, until Te Pō suddenly launched forward, and missed a strike to Tūkaha's head, who counter-struck Te Pō in the back with his taiaha "Te Ika Whero" as he stumbled by.

"Your arrogance will be your downfall," declared Tūkaha. "You might as well give up. If you do not, we shall surely kill you and your men."

Te Pō became enraged and released a flurry of strikes. His speed and power soon overcame Tūkaha. It was as if time had slowed frame-byframe for Taiao as he watched his father - like a great tôtara - fall to the ground, after being struck on the back of the head by Te Pō's taiaha.

As Te Pō relished in his victory, thirty toa (warriors) arrived as reinforcements. One of the female toa from Taiao's hapū snuck away, to alert Tūî-teKarere that Tūkaha's papa kāinga was under siege.

"I suggest that if you wish to live, that you surrender and return to your land and families" commanded Tūî, standing strong in front of his toa. "So be it, we will leave..." Te Pō retorted. "But you will all regret letting us live, the next time we will have more men and we shall be victorious," he continued with a dirty smirk. "Seeing as you SUGGEST that we leave, we will do so, oh mighty man," spat Te Pō sarcastically.

Te Pō taunted Taiao and his hapū by sweeping his taiaha from side to side while quickly stamping his feet on the dirt, creating a screen of dust (tipatapata-taiaha foot movement). As he did, he lead the ope tāua into te pō (the night).

Tūì was quick to comfort his brother's people and son. He gave assurances that their hapū would 
support them, particularly seeing their harvest and catch was plundered they would feed them. And then, when the time was right and they were ready, they would aid them in enacting utu.

"You have lost a number of warriors amidst the battle, leaving you all with only 12 capable warriors," announced Tūī, "And I also lost a brother, your rangatira, as a result of this act of treachery. But he is now leading the way to Te Rerenga Wairua. From there, they will return to Hawaiki-nui, Hawaiki-roa, Hawaiki-pamamao," Tūi said sadly, fighting back tears while comforting his nephew Taiao."I cannot take his place as rangatira of this hapū, but I can allow you all to stay at my papa kāinga, where I will be your rangatira until Tūkaha-nui is of age. Following the tangi and burial of our fallen family, those who wish to follow me to my pā may do so," Tūî soothed the mourners.

Tūî then began a waiata tangi (mourning song) and was joined by others of Taiao's hapū.

Tētahi o ngā waiata tangi ki a Tu-kaha-nui te rangatira, me ngā tāngata i mate nā te whawhai:

Rimurimu tere tere.

Tere ki te moana.

Tere ana ki te ripo $i$ waho $e$.

Tirohia ki waho nei.

E marino ana e.

Kei roto $i$ ahau.

E marangai ana e.

Kei te tio te hüka.

Ki runga i ngā hiwi.

Kei te moe koromeke.

Te wairua e.

Rite tonu tō hanga.

Ki te Tìrairaka e.

Waihoki tō hanga. 
Te wairangi e.

After the week-long tangihanga and burial, Taiao's hapū gathered their belongings and left their pā, to live amongst Tūî.

Taiao snapped out of his daze by the low whisper in his ear, "What are we going to do, what is your plan?" enquired one of his high-ranking toa.

"We will ambush on my command. Be ready," Taiao replied quietly.

While watching Te Pō, again Taiao thought back to a few years following his father's death, his obsession with avenging his father.

When they moved to Uncle Tūî's hapū, Taiao became reserved and resentful to everything, and was no longer his bubbly, pure self. Every day he plotted and devised ways that he might kill Te Pō. He would think, "I can't wait to kill him, to have my revenge for killing my father and my warriors. I'm going to cut his hands off and slit his throat. No. I'll tie rocks to his feet and feed him to the sharks. Whatever way I kill him, I'll enjoy it. He is not even worth enslaving, maybe I'll feast on his flesh, then shit him out."

After a few years of going down this rabbit-hole, he stopped interacting with others including his whānau; he became a recluse, far from who he was. He began refusing food and water, he stopped leaving his whare unnecessarily. Uncle Tūî noticed the unusual behaviours adopted by his nephew, and knew it had to be 'fixed'. Tūi spoke with Te Aratia, the tohunga (expert priestly person) of the pā, to find a solution to heal Tūkaha. With the authority of Tūî, Te Aratia placed the pā under a rāhui (ritual prohibition) for 3 days, during which 
he performed karakia and incantations to clear Taiao of his mental state, to return him to his true self, and to heal his mamae, the trauma that caused this change in him. He remembered everything; all his pain and hatred. Rage boiled within him, a desire for utu was rehashed and stronger than before. The karakia and enchantments performed by Te Aratia were now merely a door unlocked.

Taiao held his taiaha flat in front of him with the upoko (head) by his left hand. He crossed his forearms, then slowly slicing the air with the sharp edge of the raparapa (flat striking end) so that it was now in-line with his back. Skillfully, Taiao spun the taiaha slowly in his hand so that the raparapa was upright, and he pulled it back as if cocking a gun. As the hammer of the gun when it is shot, the raparapa shot forward signalling the advance, the ambush.

Taiao and his ope tāua crept up behind Te Pō's ope in a crescent-like formation. Then they pounced. There were so many toa in Taiao's ope that Te Pō and his toa had no chance. Within a minute Te Pō's entire ope were either disabled or slain. All but one; the great, the mighty Te Pō. He tried to flee, but was cut off by Taiao's ope. He hadn't changed at all from 12 years ago, the black korowai, black maro, black feathers in his black hair, and his black taiaha with tūhua (obsidian) eyes, the true embodiment of te pō, te pō nui, te pō roa, te pō uriuri (the night, the great night, the long night, the dark night). Even though Te Pō was singled out, he had to be as fierce as all his men combined, to fight with all their strength if there was any chance of survival.

Taiao's ope encircled Te Pō, caging him in. They knew that Te Pō was not to be touched, by anyone other than Taiao, all of whom were acquainted with Taiao's prowess in hand to hand and weaponry combat. They did not dare defy or 
undermine him by prematurely attacking, they would surely have faced the same imminent fate as Te Pō.

Taiao and Te Pō circled each other, just as Te Pō and Tūkaha had 12 years ago. Taiao knew he was the superior fighter; he remembered all the training Uncle Tūi made him do all of the years following Te Aratia's 'cleansing' and 'healing' karakia. Taiao trained under Tūî, a legendary fighter for 8 years, and in that time became the best in all types of combat out of everyone in the papa kāinga, even bettering his uncle. His prowess, rage, and lust for utu likened him to a taniwha. But he still had questions for Te Pō, and as they circled one another he snarled, "Before I kill you, why did you attack my hapū? Why did you kill my father and our other toa?"

"We never meant to hurt or kill anyone," replied Te Pō in an unimpressed tone.

"TEKA!" Taiao yelled, with all the hate for him and the mamae for his father. "You are a liar! If your intentions were not to kill anyone, why did you? What were your intentions?" he implored, needing to know before he executed him.

"We never wanted to kill anyone... especially not Tūkahanui," he started slowly. "We respected him. One of my toa entered into his whare to subdue him, but he was overpowered and killed." There was a slight pause, "and then he came out and wounded another two before arriving to me." Another hesitation, "we attacked your hapū because we'd run out of food. We'd planted our crops too late and were yet to yield. We would have starved," he humbly confessed. "We thought if we asked for food, we would have been turned down, so the only way we would get food, to feed our hapū was by force," explained Te Pō.

Taiao now had a moral dilemma on his hands. He remembered that prior to the attack, his hapu had a plentiful harvest because they celebrated only nights before, and could have spared some for Te Pō's hapū. 
But Te Pō was responsible for his father's death. And he was firm in his objective for utu.

"We would have spared some food for your hapū, had you asked," he hissed, "but you killed my father Tū-Kaha-Nui, rangatira of Te Aewa," he spat, tears welling his eyes at the mention of his father's name, "and that cannot be forgiven!" He let them fall, then inhaled and dropped his voice, "only by utu will your act of cowardice and utter sacrilege be re-paid and corrected."

"Duuhaa!....waaa!...urra!.uoop!.urrhaa!...dohhaa!..HO!!" bellowed Taiao as he spun his taiaha from one side to the other, swinging it over his head three times, flicking it to his side, slicing the air at head level, landing the raparapa on his neck and shoulder, and morphing his body to resemble a whare.

Just like the memory of twelve years ago Te Pō leaped to strike at Taiao, but it was met with a pare (parry) which sent him stumbling. "Your arrogance will be your downfall, old man," snared Taiao, Te Pō tried overwhelming Taiao with a flurry of strikes, but Taiao knew all of his moves.

Taiao followed through with a strong whack to the side of the knee, which sent Te Pō hurtling to the ground. "Bahahaha, it seems that in your old age you aren't as great a warrior as some may think", chuckled Taiao.

Taiao now stood over Te Pō ready to execute him; his taiaha cocked back under his arm, ready to viper strike. He thrusted the arero to Te Pō's head.

“Taihoa! Taihoa!" yelled Te Pō. "Please! Before, you kill me... there is one thing... I must tell you," he panted. "Tūkaha, was not your true father," he hesitated. He breathed in, hard. "I am," he exclaimed. 
"Rūpahu!" shouted Taiao. "It's true... I... I am a pōriro [illegitimate child], Tūkaha found out about this after you were born... when your mother, was singing your, oriori... He banished me and all the other poriro from the papa kāinga." Taiao cocked his neck, and lowered the taiaha ever so slightly. Te Pō continued, "We attacked the papa kāinga back then to retrieve you, so you could be with us, and be raised by me... Tūkaha and Tūì have been lying to you your whole life."

"I'm....ah... a," he shook his head, and squinted his eyes. Swallowing hard, Taiao said, "I'm, not... going to kill you...Pāpā," cringed Taiao. "I can't kill... my own father.

The depression. The training. The insomnia. The days and nights of plotting te utu on Te Pō. Hating him. The mamae for Tükaha-nui. The insanity.

"I will have utu..." his whole being quivered and quaked, "on TŪī, hhaaaa! TŪII-TE-KARERE... THE LYING BASTARD!!!” 